\title{
ISSO SERÁ E ISSO FOI DESTRUÍDO: AS IMAGENS DE BENTO RODRIGUES NO GOOGLE STREET VIEW
}

\author{
Marcela Vasco ${ }^{1}$
}

Em 5 de novembro de 2015, rompeu-se a barragem de rejeitos de mineração de Fundão, pertencente a Samarco, mineradora controlada pela Vale e pela BHP Billiton. Localizada a 5,5 km de Bento Rodrigues, subdistrito da cidade de Mariana, em Minas Gerais, Fundão cuspiu sobre o pequeno povoado milhões ${ }^{2}$ de metros cúbicos de rejeitos de mineração, varrendo casas, carros, capelas, mercadinhos, escola e deixando 19 vítimas fatais ${ }^{3}$. Em cerca de 10 minutos, o povoado foi quase completamente devastado. O marrom ocre da lama de rejeitos soterrou ruas e se impregnou nas poucas construções que se mantiveram de pé.

Anos antes, em julho de 2012, o carro do Google Street View percorreu a rua São Bento, principal rua do povoado. Através de um sistema de câmeras acopladas ao veículo e ligadas a um receptor GPS, imagens de vizinhos conversando na calçada, crianças andando de bicicleta, cavalos nas ruas e pessoas caminhando para algum lugar foram captadas e lançadas ao ambiente virtual do Street View. Não fosse o desastre a transformar Bento Rodrigues em ruína e pó, talvez nunca nos interessaríamos por essas imagens. Com a rompimento e a destruição do pequeno povoado, porém, as imagens de residências, comércios e da capela de São Bento ainda de pé passam a ser perturbadoras.

\footnotetext{
${ }^{1}$ Universidade Estadual de Campinas. E-mail: marcelavasco.doc@gmail.com ORCID id: https://orcid.org/0000-0003-4581-0667

${ }^{2}$ A quantidade de lama despejada sobre Bento Rodrigues é incerta. A Samarco afirma que Fundão mantinha um volume de rejeitos de aproximadamente 55 milhões de $\mathrm{m}^{3}$, dos quais 43,7 milhões de $\mathrm{m}^{3}$ passaram sobre a barragem de água de Santarém e atingiram o povoado de Bento Rodrigues (SAMARCO, 2017). De acordo com o IBAMA (2015), em laudo preliminar, foram 34 milhões de $\mathrm{m}^{3}$ dos rejeitos de Fundão lançados no meio ambiente em um primeiro momento e outros 16 milhões de $\mathrm{m}^{3}$ restantes conduzidos posteriormente, pouco a pouco, pelas chuvas.

${ }^{3}$ Ao todo, o rompimento causou a morte de 19 pessoas, sendo 14 trabalhadores que estavam na barragem, dois idosos e duas crianças moradores de Bento Rodrigues e uma senhora que passava as férias na casa de parentes no povoado. Priscila Monteiro Barros, moradora de Bento Rodrigues, alega ter sofrido um aborto em decorrência do rompimento. No dia 5 de novembro, data de seu aniversário, ela completava 28 anos e, no dia seguinte, tinha consulta marcada para saber o sexo do bebê. Como não há nenhum documento que comprove a gravidez, a Samarco não reconhece que Priscila estivesse grávida e tenha abortado em decorrência do rompimento e, portanto, não assume qualquer responsabilidade sobre o ocorrido.
} 
O filósofo Georges Didi-Huberman (2012) defende que as "imagens ardem" em contato com o real: "Não se pode falar do contato entre a imagem e o real sem falar de uma espécie de incêndio" (ibid., p. 210). As imagens do Google Street View, que apresento neste ensaio cuja fonte é o próprio Google Street View (2017) e foram editadas por mim, além de tocarem o real, nos oferecem a projeção de estarmos virtualmente em Bento Rodrigues em um dia qualquer de julho de 2012. Com registros apresentados em $360^{\circ}$, a representação virtual do ambiente proporcionada pelo Google permite caminhar virtualmente, olhar para o lado ou para trás e explorar o cenário de maneira assombrosamente próxima do real. Nesse sentido, são imagens que ardem.

Quando escreve sobre o Retrato de Lewis Payne, do fotógrafo Alexander Gardner, no qual um jovem algemado espera por seu enforcamento, Roland Barthes (1984) nos aponta que o punctum ${ }^{4}$ da imagem é que "[ele] está morto e vai morrer" (ibid., p. 143), ou seja, ao mesmo tempo, "isso será e isso foi" (ibid., p. 142, grifos do autor). Tirada em 1865, vemos um jovem prestes a morrer, que há tempos já morreu. Parafraseando Barthes, com relação às imagens de Bento Rodrigues presentes no Google Street View, sabemos que isso será e isso foi destruído.

Suspensas nas nuvens do servidor da gigante de tecnologia, essas imagens sobreviveram à destruição - diferentemente do real que tocam, bem como das muitas outras imagens que habitavam as gavetas, os armários e os porta-retratos e foram levadas pela avalanche de lama. Nos versos finais do poema Confidência do Itabirano, o mineiro Carlos Drummond de Andrade (2012) lamenta: "Itabira é apenas uma fotografia na parede/ Mas como dói!". Após sofrer consequências devastadoras da mineração, a cidade natal do poeta se tornou uma fotografia na parede que arde (DidiHuberman, 2012) e fere (Barthes, 1984). Da mesma forma, as imagens de Bento Rodrigues presentes no Google Street View são apenas uma representação virtual de um povoado mineiro, “[mas] como dói!”.

\footnotetext{
${ }^{4} \mathrm{O}$ punctum barthesiano é uma marca determinada que cada fotografia possui, é a ferida da imagem. "O punctum de uma fotografia é esse acaso que nela me fere (mas também me mortifica, me apunhala)" (Barthes, 1984, p. 35). É a abertura na imagem que a faz se oferecer não ao intelecto, mas ao corpo.
} 


\section{REFERÊNCIA}

BARTHES, Roland. A Câmara Clara: nota sobre a fotografia. Rio de Janeiro: Nova Fronteira, 1984.

DIDI-HUBERMAN, Georges. Quando as imagens tocam o real. Revista Pós, v. 2, n. 4, p. 204-219, 2012.

DRUMMOND DE ANDRADE, Carlos. Sentimento do mundo. São Paulo: Companhia das Letras, 2012.

Recebido: $10 / 02 / 2020$

Aprovado: 15/07/2020 

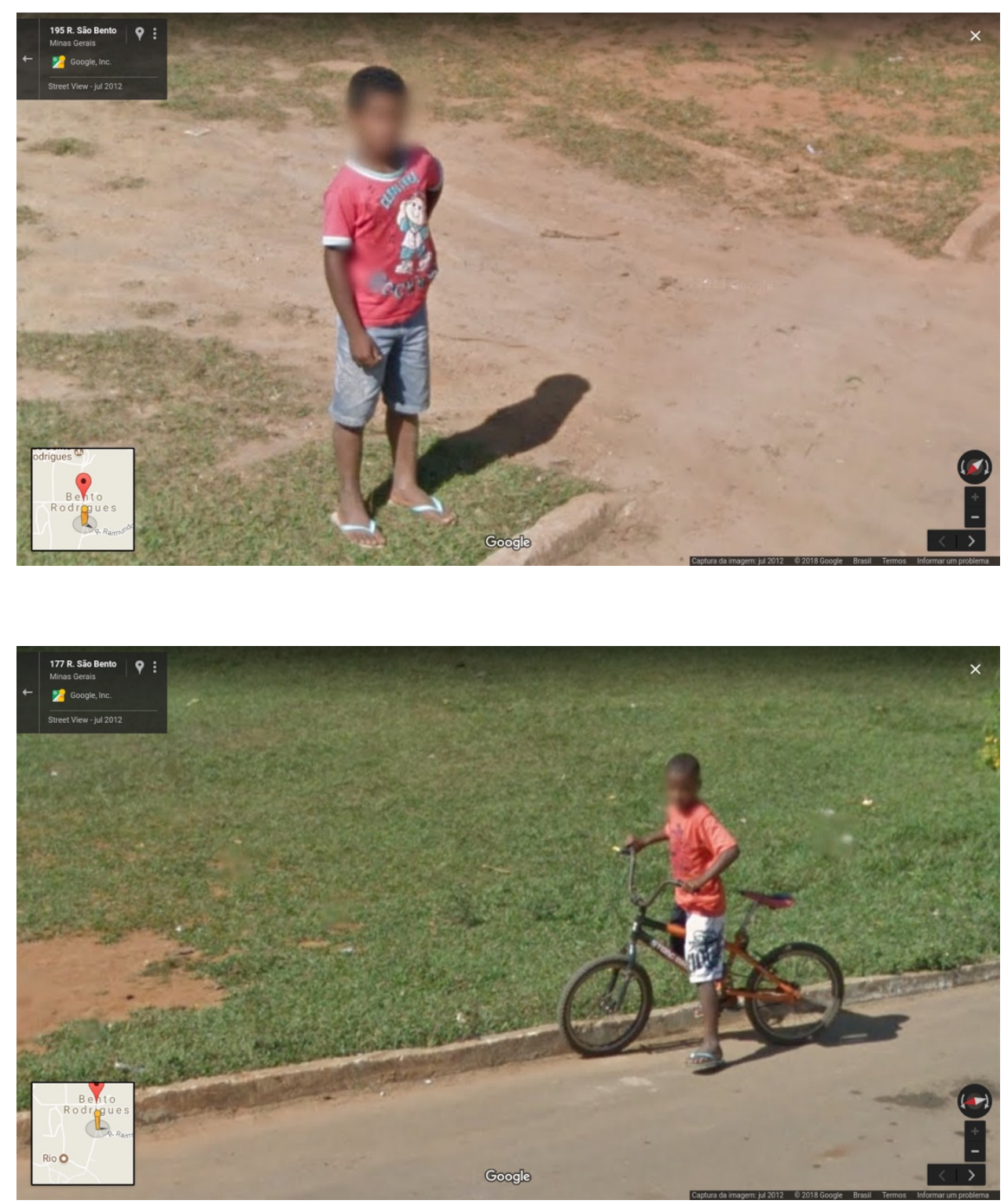

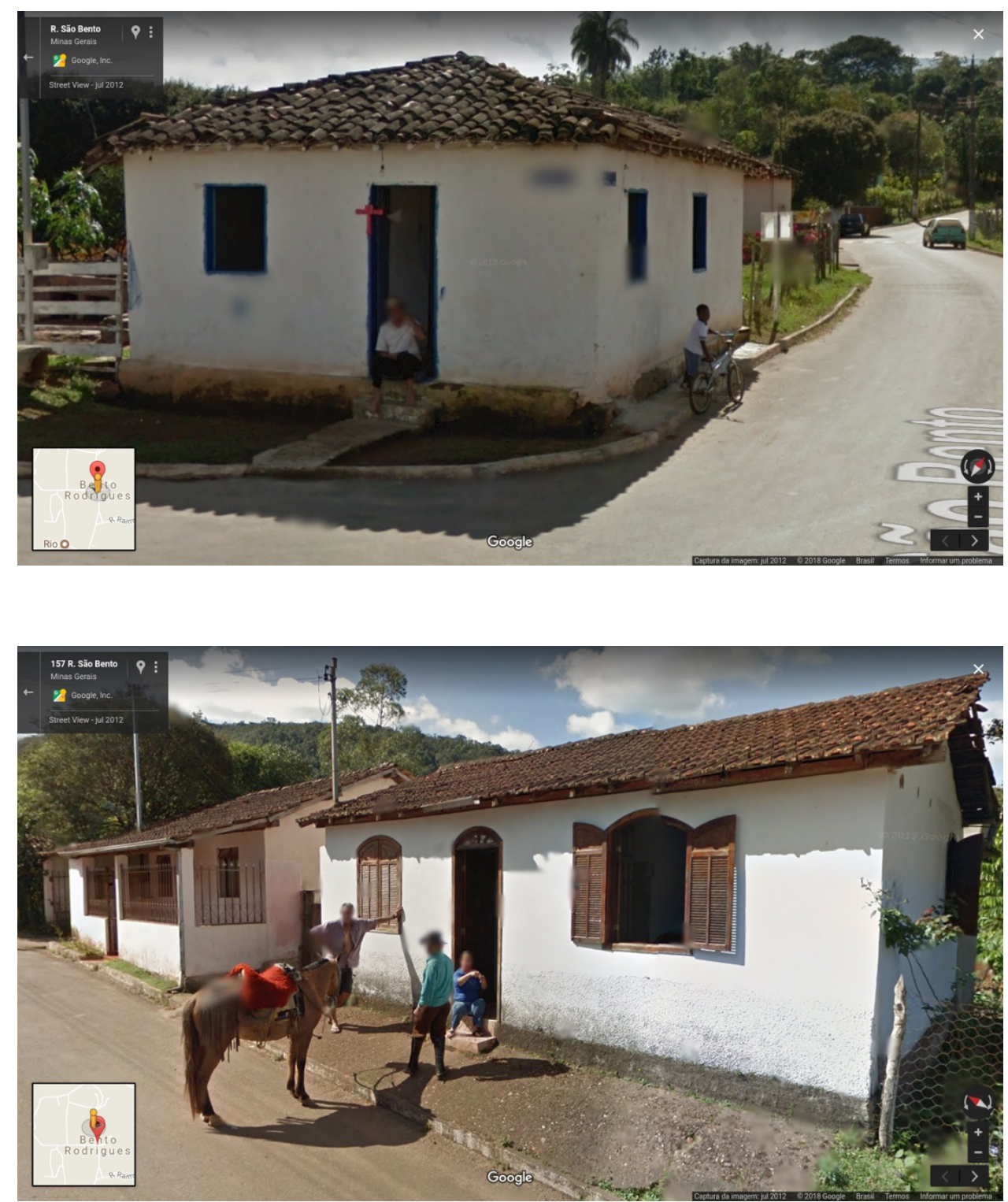

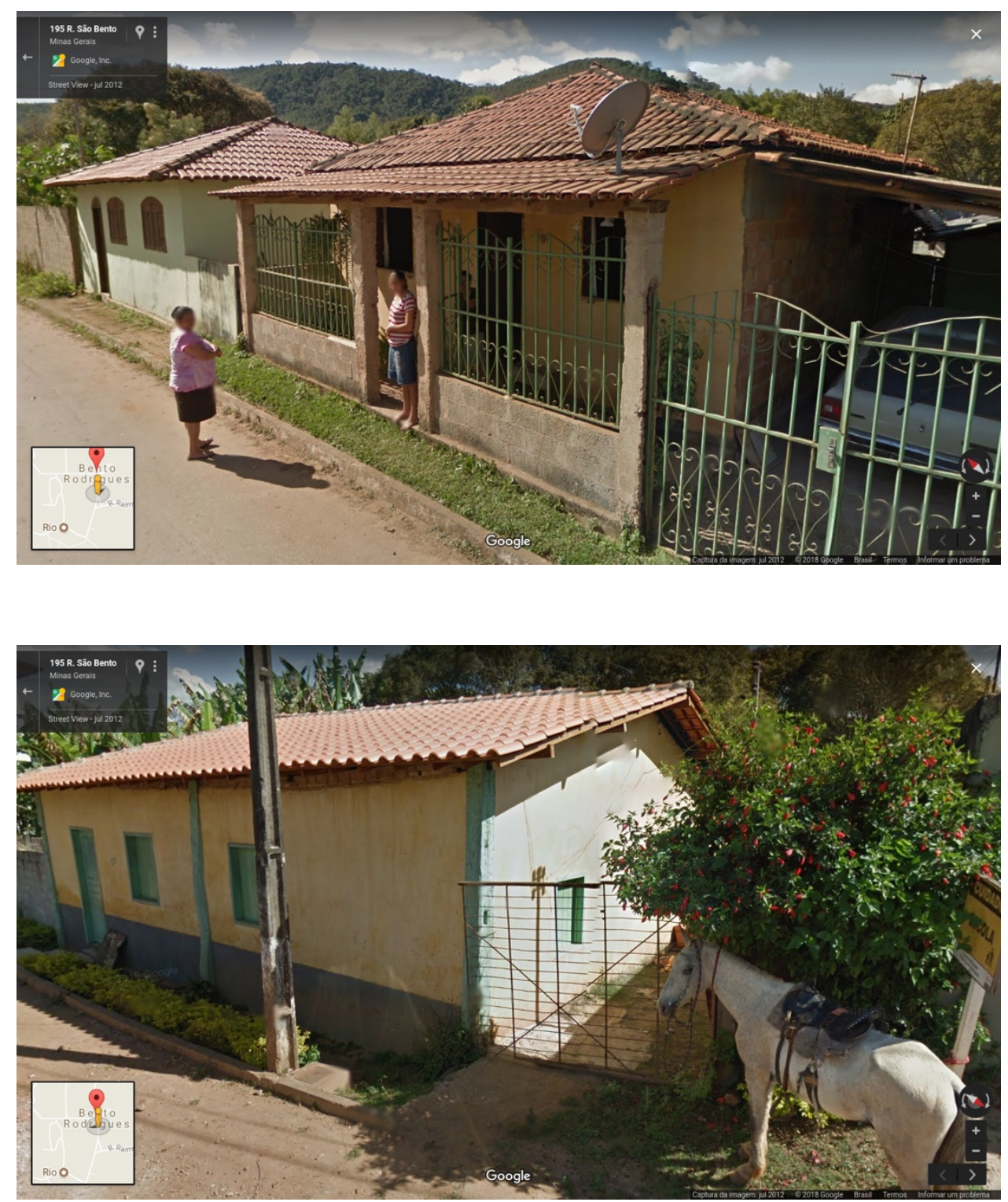

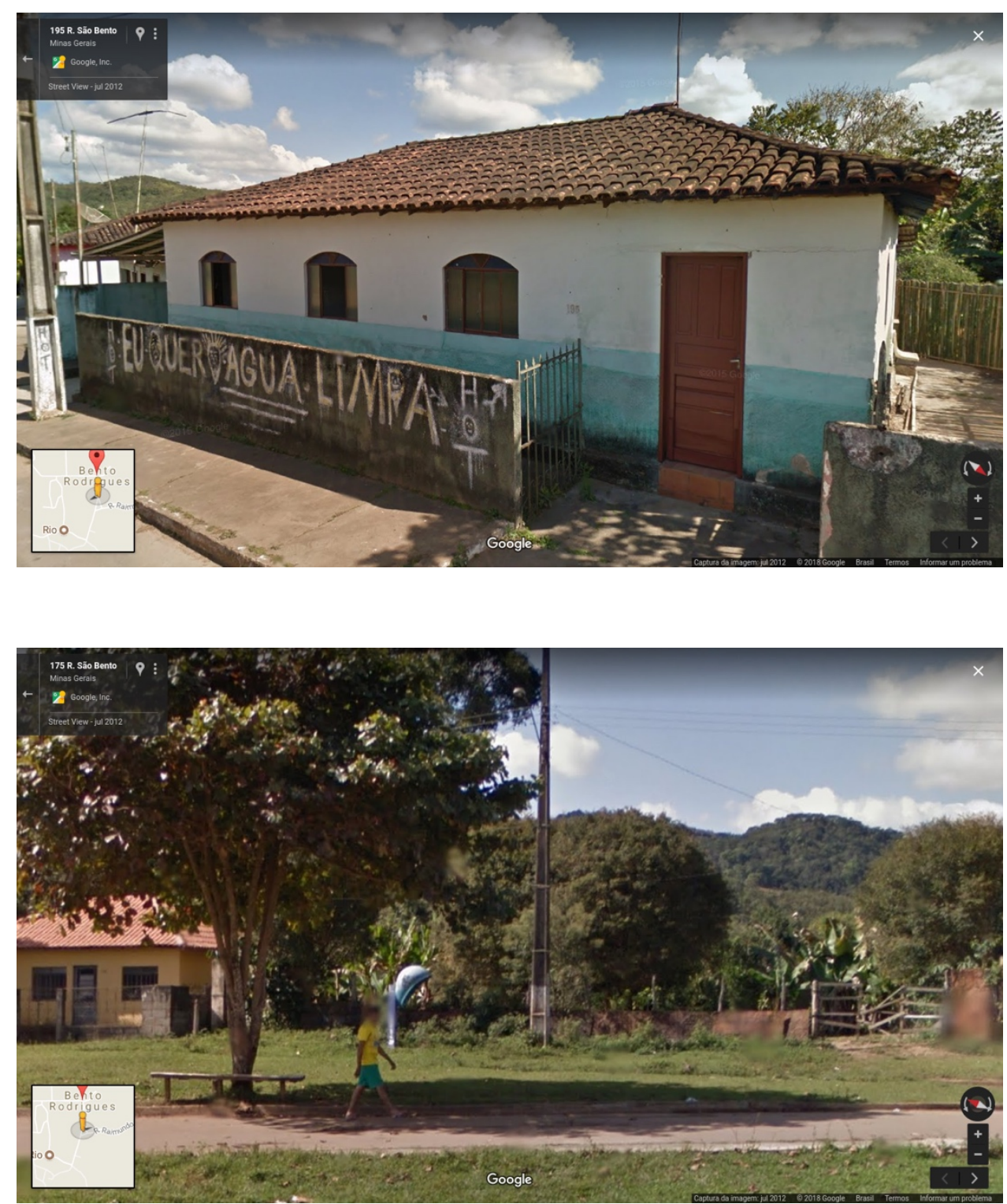